\title{
Geology
}

\section{Fire in the sea--Growth and destruction of submarine volcanoes}

\author{
Hans-Ulrich Schmincke and Mari Sumita
}

Geology 2013;41;381-382

doi: $10.1130 /$ focus0320132.1

\section{Email alerting services}

Subscribe

Permission request click www.gsapubs.org/cgi/alerts to receive free e-mail alerts when new articles cite this article

click www.gsapubs.org/subscriptions/ to subscribe to Geology

click http://www.geosociety.org/pubs/copyrt.htm\#gsa to contact GSA

Copyright not claimed on content prepared wholly by U.S. government employees within scope of their employment. Individual scientists are hereby granted permission, without fees or further requests to GSA, to use a single figure, a single table, and/or a brief paragraph of text in subsequent works and to make unlimited copies of items in GSA's journals for noncommercial use in classrooms to further education and science. This file may not be posted to any Web site, but authors may post the abstracts only of their articles on their own or their organization's Web site providing the posting includes a reference to the article's full citation. GSA provides this and other forums for the presentation of diverse opinions and positions by scientists worldwide, regardless of their race, citizenship, gender, religion, or political viewpoint. Opinions presented in this publication do not reflect official positions of the Society.

\section{Notes}

(C) 2013 Geological Society of America

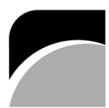

THE GEOLOGICAL SOCIETY OF AMERICA 


\title{
Fire in the sea-Growth and destruction of submarine volcanoes
}

\author{
Hans-Ulrich Schmincke and Mari Sumita \\ GEOMAR Helmholtz Centre for Ocean Research Kiel,Wischhofstrasse 1-3, 24148 Kiel, Germany
}

The appearance of a steaming volcano close to the sea surface represents a rare but spectacular geological event, because the birth of a new volcano vividly illustrates the steady yet piecemeal growth of the Earth's crust; and its simultaneous destruction.

Every volcanic eruption on land generates a quantum jump in our understanding of growth and destructive processes of volcanoes, but this is even more true underwater, although eruptions typically occur hidden from view. Loihi Seamount, $\sim 35 \mathrm{~km}$ off the southeast coast of the Big Island of Hawaii, has for many years been an instructive example. The broad range in composition of its basalts greatly changed views of the compositional evolution of Hawaii and other oceanic islands, and led to the discovery of a range of volcaniclastic products, from glassy ash to basalt breccias (Garcia et al., 1998; Clague et al., 2003). Loihi experienced an eruption in 1996 , followed by massive collapse of its top, but this top is located almost $1000 \mathrm{~m}$ below sea level, making regular, detailed observations difficult to almost impossible, if only because of the very high costs. The top of the active submarine volcano Monowai in the Kermadec Arc (north of New Zealand) rises episodically close to the water surface, changing rapidly (weeks to decades) in elevation by tens of meters, because of repeated episodes of volcano growth and rapid flank collapse (Wright et al., 2008; Watts et al., 2012). Growth and collapse rates at Monowai were very high, with the volume changes calculated as $0.11 \mathrm{~km}^{3} \mathrm{yr}^{-1}$ for collapse, and $0.63 \mathrm{~km}^{3} \mathrm{yr}^{-1}$ for growth. The 2011 lava eruption of Axial Seamount at the intersection between the Cobb hotspot and the Juan de Fuca spreading center had been forecast, based on detailed monitoring following its eruption in 1998 (Chadwick et al., 2012). Active Vailuluù Seamount close to the Samoa hot spot (present depth $590 \mathrm{~m}$ ) is growing so fast that it may reach the surface within decades (Staudigel et al., 2006).

The 2011-2012 submarine El Hierro (Canary Islands) eruption differs from the previous examples in the Pacific Ocean by having grown on the upper flank of an oceanic island close to land, allowing convenient monitoring. Many published and ongoing studies make this eruption unique. El Hierro is the youngest $(1.12 \pm 0.02 \mathrm{Ma})$ and smallest of the seven major islands of the Canarian archipelago (Guillou et al., 1996). A shallow submarine eruption occurred between 12 October 2011 and 5 March 2012, 2 km off the southern coast of the island, just offshore the sites of prehistoric eruptions dated at ca. $4000 \mathrm{yr}$ B.P. and $2500 \mathrm{yr}$ B.P. The proximity to land and the shallow depth (the new volcanoes rose from a depth of $363 \mathrm{~m}$ and finally reached $89 \mathrm{~m}$ below mean sea level [bmsl]) provide a unique opportunity to study precursor phenomena on land prior to and during the eruption, and to repeat surveys across the eruptive sites. Eight swath bathymetry surveys were carried from 22 October 2011 to 24 February 2012 by Rivera et al. (2013, p. 355 in this issue of Geology). Most remarkable are the continuous changes in form and height of the new volcano, changing from a single cone into a linear array of four cones over 4 mo. Collapse of the edifice accompanied the rise of the volcanic structure from the start, with streams of debris moving down the valley in which the new volcano was growing. The total volume of the volcanic complex was calculated as $329 \times 10^{6} \mathrm{~m}^{3}$, with the actual cone making up one third of this bulk volume. More than 200 similar cones have been identified on the submarine flanks of El Hierro by Rivera et al., the largest with volumes of $>1000 \times 10^{6} \mathrm{~m}^{3}$. The practically simultaneous episodes of collapse of the flanks were most interesting to monitor, but the large flank collapses known from all Canary Islands, as well as from other oceanic islands and volcanoes in general, have vastly larger volumes. For example, during the El Golfo debris avalanche, $~ 50-180 \mathrm{~km}^{3}$ of material was moved (Masson et al., 2002), the equivalent of $\sim 500$ of the volcanic structures of the type emplaced in 2011-2012 on El Hierro (Rivera et al., 2013).

All eruptions of submarine volcanoes are, as expected, accompanied by seismic swarms, with the largest earthquake swarm in the Hawaiian Islands, in July and August 1996, occurring on Loihi seamount several months after pyroclastic activity, during the collapse of the Pele's Pit crater (Davis and Clague, 1998; Garcia et al., 2006). Most small $(\mathrm{M}<2.5)$ earthquakes on El Hierro started on 19 July 2011 along a north-southoriented belt at 8-15 km depths (Ibáñez et al., 2012; Lopez et al., 2012). Seismicity migrated south during the second half of September, increasing in magnitude and peaking with an M 4.4 earthquake on 8 October at $14 \mathrm{~km}$, followed on 12 October by continuous tremor, reflecting rapid rise of the magma to the surface, water discoloration, and steaming vesicular volcanic bombs floating on the water, $\sim 2 \mathrm{~km}$ south of the village of La Restinga in the south of El Hierro. Ibañez et al. (2012) infered that the initial earthquakes reflected magma migration from the upper mantle to crustal depths, where high fracturing would favor anomalously high $b$-values of the frequency-magnitude distribution of up to 2.25 ( $b$-values in volcanic regions sometimes reaching 3). The larger-magnitude earthquakes with lower $b$-values (1.25) are interpreted by Ibañez et al. (2012) to reflect relaxation around the magma reservoir.

Monitoring of diffusive degassing is important for volcanic surveillance. At the beginning of the seismic activity, magma movement beneath El Hierro generated new fractures and microfractures, causing anomalously high, but diffuse, deep-seated degassing on land prior to the submarine eruption (Pérez et al., 2012). Helium ascended from depth through structures of high vertical permeability, thereby enhancing the helium content of soil gases, and with an increase in mantle-derived gases recorded by the ${ }^{3} \mathrm{He} /{ }^{4} \mathrm{He}$ ratio preceding seismic energy release (Pádrón et al., 2013).

Curious steaming bombs of highly vesicular scoriaceous basalt floated in the turbulent, turbid whirlpool above the submarine vent off Restinga, and resembled bombs from shallow-water submarine eruptions in the Azores (Gaspar et al., 2003) and Socorro Island (off Mexico) (Siebe et al., 1995). The balloons soon collapsed and fragmented, fragments sinking to the bottom within a few tens of minutes. Deposits composed of irregularly shaped, commonly curved, fragments of vesicular basalt are well-exposed in the upper part of the uplifted seamount complex of La Palma Island just north of El Hierro, and were interpreted as reflecting the growth of the seamount to near the surface (Staudigel and Schmincke, 1984; Schmincke and Sumita, 2010, their figures 4.20-4.23).

Many bombs consist of highly vesicular white cores mixed with, and surrounded by, black basanitic crusts, the composition and origin of the white enigmatic material being hotly debated. At issue was not the old question of whether or not the Canary Islands are underlain by continental or oceanic crust; the latter underlies all of the archipelago (Schmincke et al., 1998). However, one of the fundamental differences between the Canaries and most other oceanic islands including Hawaii is the huge volume of highly evolved magmas generated beneath Tenerife, and especially beneath Gran Canaria, where possibly as much as $1000 \mathrm{~km}^{3}$ of rhyolitic to phonolitic ignimbrites were erupted and intruded from a $20-\mathrm{km}$-diameter caldera between 14 and 9 Ma (Schmincke and Sumita, 2010), with 
overwhelming evidence that crystal fractionation controls the generation of these highly evolved magmas. Meletlidis et al. (2012) interpreted the white $\mathrm{SiO}_{2}$-rich material of the bombs as pockets of trachyte and remelted hydrothermal material of rhyolitic composition, accumulated in the substructure of Hierro and reheated and mobilized by the newly risen basanitic magma. No highly evolved volcanic rocks are known from the island of El Hierro, which is in an early stage of evolution and dominated by primitive basanitic magmas. Troll et al. (2011) view the white pumice as oceanic sediments of layer 1 , re-melted at contact by the basanitic magma. The occurrence of these "restingolites" (referring to the proximity of the village La Restinga) suggests that crustal recycling is relevant in ocean islands, especially in the eastern Atlantic Ocean where their flanks are deeply buried in marine sediments, with a large clastic input from Africa. This interpretation is backed up by studies of variably re-melted, more or less pumiceous, sediments from many Canary Islands, as in the 1949 eruption of La Palma (Klügel et al., 1999).

The eruption off El Hierro was a blessing in disguise for increasing the awareness of the Canarian people (and the millions of tourists flocking there annually) to volcanic hazards and risks. The first major broad-scale efforts to alert the population to the possibility of volcanic eruptions were made in conjunction with the successful international conference "Cities on Volcanoes," in Tenerife in May 2010. The Instituto Volcanológico de Canarias (INVOLCAN) opened then, and scientists helped to advise the Civil Protection agency (PEVOLCA) on volcanic risk management of the El Hierro eruption. As there was no previous experience with submarine eruptions in the Canary Islands, there was initial confusion and uncertainty as to if, and when, to evacuate people. Curiously, a statistical "prediction" that the next volcanic eruption in the Canary Islands might be due in 2011 was published in June 2011, based on the observation that historical volcanic eruptions on the islands are on average spaced $\sim 40 \mathrm{yr}$ apart, the most recent eruption having occurred in 1971 on the southern tip of neighboring La Palma just opposite El Hierro (Schmincke and Sumita, 2011).

In summary, the rich scientific harvest of the 2011-2012 El Hierro submarine eruption has just started to come in, and much more is expected in the near future. The apparent absence of true explosive activity is puzzling in view of the fact that the depth range of the eruption is fairly shallow, and the El Hierro magmas are alkalic basanites, so that dredging of the eruptive products is especially important.

We thank Bill Chadwick, David Clague, and Ellen Thomas for helpful comments on this article.

\section{REFERENCES CITED}

Chadwick, W.W. Jr, Nooner, S.L., Butterfield, D.A., and Lilley, M.D., 2012, Seafloor deformation and forecasts of the April 2011 eruption at Axial Seamount: Nature Geoscience, v. 5, p. 474-477, doi:10.1038/ngeo1464.

Clague, D.A., Batiza, R., Head, J., and Davis, A.S., 2003, Pyroclastic and hydroclastic deposits on Loihi Seamount, Hawaii, in White, J.D.L. et al., eds., Explosive Subaqueous Volcanism: American Geophysical Union Monograph 140, p. 73-95, doi:10.1029/140GM05.

Davis, A.S., and Clague, D.A., 1998, Changes in the hydrothermal system at Loihi Seamount after the formation of Pele's pit in 1996: Geology, v. 26, p. 399-402.

Garcia, M.O., Caplan-Auerbach, J., De Carlo, E.H., Kurz, M.D., and Becker, N., 2006, Geology, geochemistry and earthquake history of Loihi Seamount Hawaii's youngest volcano: Chemie der Erde Geochemistry, v. 66, p. 81108, doi: 10.1016/j.chemer.2005.09.002.

Garcia, M.O., Rubin, K.H., Norman, M.D., Rhodes, J.M., Graham, D.W., Muenow, D.W., and Spencer, K., 1998, Petrology and geochemistry of basalt breccia from the 1996 earthquake swarm of Loihi seamount, Hawaii; Magmatic histroy of its 1996 eruption: Bulletin of Volcanology, v. 59, p. 577592, doi:10.1007/s004450050211.

Gaspar, J.L., Queiroz, G., Pacheco, J.M., Ferreira, T., Wallenstein, N., Almeida, M.H., and Coutinho, R., 2003, Basaltic lava balloons produced during the
1998-2001 Serreta Submarine Ridge eruption (Azores), in White, J.D.L. et al., eds., Explosive Subaqueous Volcanism: American Geophysical Union Monograph 140, p. 205-212.

Guillou, H., Carracedo, J.C., Pérez Torrado, F., and Rodríguez Badiola, E., 1996, $\mathrm{K}-\mathrm{Ar}$ ages and magnetic stratigraphy of a hotspot-induced, fast grown oceanic island: El Hierro, Canary Islands: Journal of Volcanology and Geothermal Research, v. 73, p. 141-155, doi:10.1016/0377-0273(96)00021-2.

Ibáñez, J.M., De Angelis, S., Díaz-Moreno, A., Hernández, P., Alguacil, G., Posadas, A. and Pérez, N., 2012, Insights into the 2011-2012 submarine eruption off the coast of El Hierro (Canary Islands, Spain) from statistical analyses of earthquake activity: Geophysical Journal International, v. 191, 659-670, doi: 10.1111/j.1365-246X.2012.05629.x

Klügel, A., Schmincke, H.-U., White, D.L., and Hoernle, K.A., 1999, Chronology and volcanology of the 1949 multi-vent rift-zone eruption on La Palma (Canary Islands): Journal of Volcanology and Geothermal Research, v. 94, p. 267-282, doi:10.1016/S0377-0273(99)00107-9.

Lopez, C., and 29 others, 2012, Monitoring the volcanic unrest of El Hierro (Canary Islands) before the onset of the 2011-2012 submarine eruption: Geophysical Research Letters, v. 39, doi:10.1029/2012GL051846.

Masson, D.G., Watts, A.B., Gee, M.J.R., Urgeles, R., Mitchell, N.C., Le Bas, T.P., and Canals, M., 2002, Slope failures on the flanks of the western Canary Islands: Earth-Science Reviews, v. 57, p. 1-35, doi:10.1016/S0012-8252 (01)00069-1.

Meletlidis, S., Di Roberto, A., Pompilio, M., Bertagnini, A., Iribarren, I., Felpeto, A., Torres, P.A., and D'Oriano, C., 2012, Xenopumices from the 2011-2012 submarine eruption of El Hierro (Canary Islands, Spain): Constraints on the plumbing system and magma ascent: Geophysical Research Letters, v. 39, doi:10.1029/2012GL052675

Padrón, E., and 13 others, 2013, Diffusive helium emissions as a precursory sign of volcanic unrest: Geology, doi: 10.1130/G34027.1 (in press).

Pérez, N.M., Padilla, G.D., Padrón, E., Hernández, P.A., Melián, G.V., Barrancos, J., Dionis, S.,Nolasco, D., Rodríguez, F., Calvo, D., and Hernández, I., 2012, Precursory diffuse $\mathrm{CO}_{2}$ and $\mathrm{H}_{2} \mathrm{~S}$ emission signatures of the 2011-2012 El Hierro submarine eruption: Canary Islands: Geophysical Research Letters, v. 39, doi:10.1029/2012GL052410.

Rivera, J., Lastras, G., Canals, M., Acosta, J., Arrese, B., Hermida, N., Micallef, A., Tello, O., and Amblas, D., 2013, Construction of an oceanic island: Insights from the El Hierro (Canary islands) 2011-2012 submarine volcanic eruption: Geology, v. 41, p. 355-358, doi:10.1130/G33863.1.

Schmincke, H.-U., and Sumita, M., 2010, Geological Evolution of the Canary Islands: Koblenz, Germany, Görres-Verlag, 200 p.

Schmincke, H.-U., and Sumita, M., 2011, Der Kanarische Archipel vor Nordwest Afrika: Wachstum und Zerfall von Vulkaninseln: Geographische Rundschau, v. 63, p. 18-25 (in German).

Schmincke, H.-U., Klügel, A., Hansteen, Th., Hoernle, K., and van den Bogaard, P., 1998, Samples from the Jurassic ocean crust beneath Gran Canaria, La Palma, and Lanzarote (Canary Islands): Earth and Planetary Science Letters, v. 163, p. 343-360, doi:10.1016/S0012-821X(98)00168-X.

Siebe, C., Komorowski, J.-C., Navarro, C., McHone, J., Delgado, H., and Cortes, A., 1995, The 1993 submarine eruption near Socorro Island, Mexico: Journal of Volcanology and Geothermal Research, v. 68, p. 239-271, doi:10.1016/0377 -0273(95)00029-1.

Staudigel H., and Schmincke H.-U., 1984, The Pliocene seamount series of La Palma/ Canary Islands: Journal of Geophysical Research, v. 89, p. 11195-11215.

Staudigel, H., and 18 others, 2006, Vailulu'u seamount, Samoa: Life and death on an active submarine volcano: Proceedings of the National Academy of Sciences of the United States, v. 103, p. 6448-6453.

Troll V.R., and 18 others, 2011, Floating sandstones off El Hierro (Canary Islands, Spain): The peculiar case of the October 2011 eruption: Solid Earth, v. 3, p. 975-999, doi:10.5194/sed-3-975-2011.

Watts, A.B., Peirce, C., Grevemeyer, I., Paulatto, M., Stratford, W., Bassett, D., Hunter, J.A., Kalnins, L.M., and de Ronde, C.E.J., 2012, Rapid rates of growth and collapse of Monowai submarine volcano in the Kermadec Arc: Nature Geoscience, v. 5, p. 510-515, doi:10.1038/ngeo1473.

Wright, I.C., Chadwick, W.W., Jr., de Ronde, C.E.J., Reymond, D., Hyvernaud, O., Gennerich, H.H., Stoffers, P., Mackay, K., Dunkin, M.A., and Bannister, S.C., 2008, Collapse and reconstruction of Monowai submarine volcano, Kermadec arc, 1998-2004: Journal of Geophysical Research, v. 113, p. B08S03, doi:10.1029/2007JB005138.

Printed in USA 